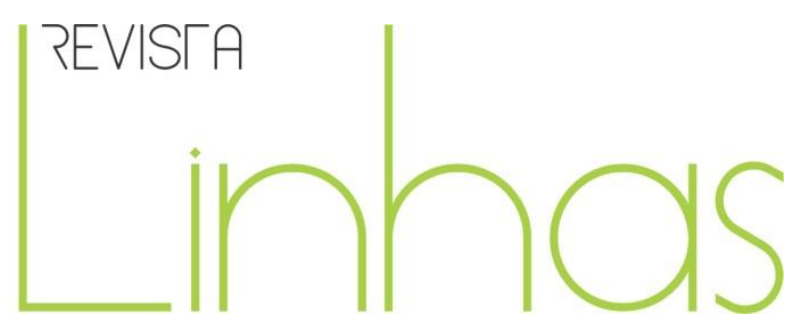

\title{
Padrão neoliberal de acumulação, ideologia e mercantilização da educação superior
}

\begin{abstract}
Resumo
O artigo trata das relações existentes entre padrão de acumulação de capital, ideologia e mercantilização da educação superior. Parte do conceito de ideologia, utilizando-se do projeto de universidade elaborado pelo Sindicato Nacional dos Docentes de Instituições de Ensino Superior - Andes-SN, e discute a mercantilização como impulso inerente à reprodução ampliada do capital, para, depois, apresentar o quadro de mercantilização e privatização em que se encontra a educação superior num momento de crise do padrão neoliberal de acumulação de capital. Ao final, apresenta desafios com os quais o projeto do Andes-SN se depara e aponta para a necessária unificação das diversas lutas realizadas pelas comunidades acadêmicas - pautas corporativas e identitárias - com as demais forças sociais que personificam o trabalho. O projeto defendido pelo Andes-SN só pode avançar se assumido na práxis das forças do trabalho, pois essa luta dirige-se a um horizonte que pressupõe transformações estruturais da sociedade brasileira.
\end{abstract}

Palavras-chave: Padrão de acumulação de capital; ideologia; mercantilização da educação superior.

\section{Para citar este artigo:}

MACÁRIO, Epitácio. Padrão neoliberal de acumulação, ideologia e mercantilização da educação superior.

Revista Linhas. Florianópolis, v. 22, n. 49, p. 14-49, maio/ago. 2021.

DOI: $10.5965 / 1984723822492021014$

http://dx.doi.org/10.5965/1984723822492021014 


\title{
Neoliberal pattern of accumulation, ideology and commodification of higher education
}

\begin{abstract}
The article deals with the relationship between the pattern of capital accumulation, ideology, and the commodification of higher education. It starts with the concept of ideology, using the university project developed by the Sindicato Nacional dos Docentes de Instituições de Ensino Superior - Andes-SN (National Union of Teachers of Higher Education Institutions), discusses commodification as an inherent impulse to the expanded reproduction of capital, and then presents the picture of commodification and privatization in which higher education is at a time of crisis in the neoliberal pattern of capital accumulation. At the end, there are challenges that the Andes-SN project faces and then, it points to the necessary unification of the various struggles carried out by academic communities - corporate and identity guidelines - with the other social forces that embody the work. The project defended by Andes-SN can only advance if assumed in the praxis of the work forces, as this struggle is directed towards a horizon that presupposes structural transformations of Brazilian society.
\end{abstract}

Keywords: Capital accumulation pattern; ideology; commodification of higher education. 
Quais as condições atuais da disputa ideológica e política em torno da educação superior no Brasil? Essa é a questão central do presente artigo que se fundamenta em exploração teórica e em análise de dados quantitativos.

A educação superior é aqui analisada como território disputado por interesses privados e públicos, como empreendimento empresarial visando lucros ou bem social. Trata-se, portanto, de um terreno transpassado por ideologias e forças políticas conflitantes: umas que atuam na defesa de sua subsunção à lógica do padrão neoliberal de acumulação de capital e outras que lutam por torná-la um bem social público garantido pelo Estado.

Para responder à questão levantada, caracterizamos, primeiramente, o conflito de interesses que permeia as instituições de ensino superior (IES); no segundo movimento, argumentamos sobre a expansão da lógica mercantil como inerente à reprodução do capital; em seguida, apresentamos o estado de mercantilização e privatização do ensino superior sob o padrão neoliberal de acumulação implantado no Brasil desde o fim da ditadura empresarial-militar; e, por fim, concluímos refletindo sobre os desafios postos para as formas de contraconsciências ou ideologias críticas que defendem a educação superior como bem social a ser garantido pelo Estado brasileiro.

\section{A disputa ideológica da universidade brasileira}

Partimos da formulação do filósofo húngaro István Mészáros sobre ideologia com o fim de confrontar a proposta do Sindicato Nacional dos Docentes de Instituições de Ensino Superior (ANDES-SN) para a universidade brasileira e a realidade do ensino superior. Outro objetivo é refletir sobre as possibilidades concretas de encaminhamento das lutas empreendidas pelo Sindicato contra o ethos mercantil e privatista que marca medularmente a educação superior no país.

Nas sendas abertas por Györg Lukács - de quem foi aluno, assistente, companheiro e amigo -, Mészáros supera a concepção segundo a qual a ideologia é definida em termos gnosiológicos, isto é, pelo contraponto do que é falso ao que é verdadeiro. Segundo essa perspectiva, o que caracteriza uma ideologia é o fato de ela 
expressar a realidade de modo errôneo, invertido. ${ }^{1}$. Seria, pois, uma ideia que falseia os fatos, direcionando a consciência das pessoas para uma compreensão e ação erradas. Assim, o conceito se define em função do lugar que determinada ideia ocupa no diapasão antitético do verdadeiro vs. falso.

Para Mészáros, todavia, a falsidade ou veracidade de uma ideia não faz dela uma ideologia, senão a função prática que ela desempenha na tomada de consciência e no encaminhamento do conflito social, no interior das sociedades classistas. Sua concepção remete, pois, a "uma forma específica de consciência social, materialmente ancorada e sustentada [...] insuperável nas sociedades de classe”. Prossegue o autor,

Sua persistência obstinada se deve ao fato de ela se constituir objetivamente (e reconstituir-se constantemente) como consciência prática inevitável das sociedades de classe, relacionada com a articulação de conjuntos de valores e estratégias rivais que visam ao controle do metabolismo social sob todos os seus principais aspectos. Os interesses sociais que se revelam ao longo da história e se entrelaçam de modo conflituoso manifestam-se, no plano da consciência social, na grande diversidade de discursos ideológicos relativamente autônomos (mas de forma nenhuma independentes), que exercem forte influência mesmo sobre os processos materiais mais tangíveis do metabolismo social. (MÉSZÁROS, 1996, p. 23)

Como consciência prática inevitável das sociedades de classe, as ideologias articulam um conjunto de valores e estratégias rivais que visam ao controle do metabolismo social e se manifestam, no plano da consciência social, na diversidade de discursos que exercem forte influência sobre os processos materiais. As ideologias são, pois, a mediação pela qual classes e grupos sociais elaboram seus interesses e intentam conscientizar as pessoas,

\footnotetext{
${ }^{1}$ No A ideologia alemã, Marx e Engels fornecem sólidos argumentos para a compreensão de ideologia como expressão da materialidade da vida social. Se, na consciência, os processos materiais aparecem invertidos é porque eles se apresentam assim na própria realidade. "Os homens são os produtores de suas representações, ideias e assim por diante, mas apenas os homens reais e ativos, conforme são condicionados através de um desenvolvimento determinado de suas forças de produção e pela circulação correspondente às mesmas, até chegar as suas formações mais distantes. A consciência (Bewusstsein) não pode ser jamais diferente do que o ser consciente (bewusstes Sein), e o ser dos homens é um processo de vida real. Se em toda a ideologia, os homens e suas relações aparecerem invertidos como em uma câmara obscura, este fenômeno provém igualmente de seu processo histórico de vida, assim como a inversão dos objetos ao se projetarem sobre a retina provém de seu processo diretamente físico." (MARX; ENGELS, 2007, p. 48). Como se depreende da citação, a inversão ou falseamento do real não é condição necessária, tampouco suficiente, para definir uma ideologia, razão porque a perspectiva meszariana nos parece a mais adequada, inclusive porque fornece base para a caracterização de formas de contraconsciência como ideologias críticas.
} 
buscando o engajamento destas em suas estratégias de disputa no interior do conflito que se desdobra na sociedade.

Na nossa perspectiva, as palavras do eminente filósofo húngaro se aplicam para ideologias abrangentes, cuja função é manter e legitimar ou questionar e transgredir a estrutura social em sua totalidade, como também se referem aos projetos direcionados à manutenção/reprodução ou à crítica/transformação de subsistemas parciais no interior do metabolismo social. Neste último caso, enquadram-se os projetos de universidade que disputam o sentido, a direção e o controle da educação superior no país e das instituições que a sustêm.

Isso posto, afirmamos que as concepções de educação em geral, e do ensino superior em particular, que se confrontam na sociedade brasileira constituem “ideologias" na medida em que articulam um conjunto de valores e estratégias que orientam a consciência e a ação prática das pessoas e de organizações da sociedade civil. Ademais, todas elas nascem e se enraízam - por várias mediações - no conflito entre as classes fundamentais, além de remeterem à questão nacional e ao modelo de sociedade que as produz e que se pretende construir. Assim, os projetos de universidade são transpassados por orientações político-ideológicas que mantêm uma postura positiva ou negativa em face da realidade brasileira - mirando a sua manutenção ou a sua transformação. Os projetos de universidade se ligam, assim, por diversas mediações, ao conflito basilar entre as forças do trabalho e as forças do capital.

O ANDES-SN tem tido papel fundamental nessa disputa na sociedade brasileira. Sua trajetória o patenteia como o principal sujeito coletivo a elaborar, empunhar e protagonizar um projeto alternativo de universidade, que expressa a antítese estrutural do ensino superior tal como existe na realidade nacional. Por isso, consideramos seu projeto como uma ideologia crítica.

Em seu Caderno 2 (2013), o ANDES-SN assenta as bases e princípios de um projeto de universidade que, mediando-se com as possibilidades presentes, aponta para a construção de um sistema de educação superior fincado, dentre outros atributos, na esfera pública ${ }^{2}$, na liberdade de expressão e na indissociabilidade do ensino, da pesquisa

\footnotetext{
${ }^{2}$ Consoante aos preceitos constitucionais, a educação, em qualquer de seus níveis e modalidades, é direito da sociedade e um bem público, podendo ser operada por instituições públicas ou privadas. O controle e
} 
e da extensão. Para efeito do argumento central do presente artigo, vale frisar tais princípios ao pé da letra:

1. manutenção e ampliação do ensino público e gratuito; 2 . autonomia e funcionamento democrático da universidade, com base em colegiados e cargos de direção eletivos; 3. estabelecimento de um padrão de qualidade para o ensino superior que estimule a pesquisa e a criação intelectual nas universidades; 4. dotação de recursos públicos orçamentários suficientes para o ensino e a pesquisa nas universidades públicas; 5. criação de condições para adequação da universidade à realidade brasileira; 6 . garantia do direito à liberdade de pensamento nas contratações e nomeações para a universidade, bem como no exercício das funções e atividades acadêmicas [...]. (ANDES-SN, 2013, p. 11)

Esses princípios só cumprem a função orientadora das lutas empreendidas pelo Sindicato porque são desdobrados em propostas efetivas, que se situam no limiar da realidade posta e do horizonte perseguido. Tais propostas, contudo, só podem ganhar materialidade na ação prática dos sujeitos envolvidos nos processos sociais imediatamente, as comunidades acadêmicas e, mediatamente, outros sujeitos sociais interessados na produção e socialização de conhecimentos voltados para os problemas da nação e da maioria da sociedade.

Parece ambígua a condição ou a natureza dos princípios acima aludidos, pois, por um lado, têm de levar em conta as condições imediatamente existentes ou postas no presente, e, de outra parte, colocam um pé para dentro do novo território, isto é, da realidade que se pretende construir. É isso que se depreende da ideia de expansão do ensino público com financiamento estatal, de funcionamento democrático das instituições que devem gozar de autonomia, de garantia da liberdade de pensamento e criação científica e cultural, da indissociabilidade entre ensino, pesquisa e extensão. Nessa direção, é instrutivo o que se afirma no Caderno 2 sobre a pesquisa dentro das universidades:

6. A pesquisa é uma atividade intelectual de caráter artesanal, devendo ser valorizada como um instrumento de desenvolvimento soberano científico, tecnológico, cultural, artístico, social e econômico - do país,

\footnotetext{
fiscalização deve ser de exclusividade do Estado brasileiro, em conformidade com as leis vigentes e tendo em vista atender ao seu objetivo primordial. A Constituição Federal, em seu art. 209 estabelece que "O ensino é livre à iniciativa privada, atendidas as seguintes condições: I - cumprimento das normas gerais da educação nacional; II - autorização e avaliação de qualidade pelo Poder Público" (BRASIL, 1988, art. 209). As finalidades da educação superior estão assentadas na Lei 9.394/96 (LDB), art. 43, I-VIII.
} 
não podendo ser submetida a critérios de produção industrial ou de mercado, devendo respeitar as condições específicas das diversas áreas do conhecimento no desenvolvimento do trabalho acadêmico;

7. Nenhum trabalho de pesquisa realizado na universidade pode ser submetido a qualquer forma de contrato que imponha condições de segredo ou de não divulgação pública. (ANDES-SN, 2013, p. 20)

A suposta ambiguidade dos princípios orientadores do projeto de universidade defendido pelo Sindicato é própria da natureza das ideologias críticas, pois estas apanham e expressam o real como síntese do imediatamente posto e do seu devir, do que é empiricamente e do que pode tornar-se. Quando tais princípios apontam apenas o horizonte, sem determinar o caminho até lá, caem na condição de apelos abstratos e vazios; se, por outro lado, apenas referem ao aqui e agora da realidade, não podem apontar qualquer superação positiva das contradições existentes e caem prisioneiros do pragmatismo, que apenas afirma o que está posto. Ao contrário, os princípios do Sindicato desempenham função ideológica precisamente porque indicam a finalidade a alcançar (o horizonte) e, partindo das contradições no ensino superior brasileiro, apontam as mediações efetivas para a conquista de uma nova universidade. Por esta sua condição aparentemente ambígua, as ideologias críticas enfrentam enormes dificuldades para se materializar na práxis social.

A esse respeito, é muito instrutiva a formulação de Mészáros sobre as vantagens de que desfrutam as ideologias dominantes e, por suposto, as desvantagens das formas de "contraconsciência" - ou das ideologias críticas, como vimos chamando - no evolver do conflito social. Na medida em que as primeiras "assumem uma atitude positiva diante das relações de produção dominantes, assim como diante dos mecanismos auto reprodutivos fundamentais da sociedade", elas

podem contar, em suas confrontações ideológicas, com o apoio das principais instituições econômicas, culturais e políticas do sistema geral. [...] uma vez que se identificam "interiormente" [...] com os processos contínuos de reprodução socioeconômica e político-ideológica, podem estipular a "praticabilidade" como pré-requisito absoluto para a avaliação da seriedade ou da inadmissibilidade categórica da crítica, bem como da legitimidade da mudança social. [...].

Além disso, dada sua posição privilegiada na ordem social dominante, elas podem ditar as condições e regras gerais do próprio discurso ideológico. (MÉSZÁROS, 1996, p. 226-227) 
Sobressaem na citação meszariana três condições favoráveis às ideologias dominantes que permeiam, inequivocamente, as circunstâncias em que se dão as lutas do Sindicato em prol de seu projeto de universidade.

A primeira refere-se ao fato de as ideologias dominantes contarem com as principais instituições econômicas, culturais e políticas do sistema em geral. Ora, a universidade é uma das instituições que detém papel fundamental no travejamento da dinâmica reprodutiva do sociometabolismo do capital. Pela sua função social, as instituições de ensino superior (IES) são instadas a propagarem a lógica dominante, encarnando-a na sua própria estrutura didático-científica e administrativa. Essa incorporação da lógica do capital pelo ensino superior se dá, porém, num terreno de tensões e contradições, em que as ideologias antissistêmicas (ou as formas de “contraconsciência”, como quer Mészáros) também comparecem.

A segunda refere-se à imposição do critério da praticabilidade como pré-requisito absoluto de toda forma de pensamento e de prática social. Sob o manto do pragmatismo, as IES são compelidas a moverem-se segundo as estreitas possibilidades impostas pelos interesses imediatos do padrão de acumulação de capital e pelas frações de classe dominantes que personificam tais interesses. A socialização do estoque de conteúdos científico-técnicos existentes e a prospecção de novos conhecimentos passam a ser informadas por um pragmatismo rasteiro, que legitima o mundo ralo e áspero das relações capitalistas. $\mathrm{O}$ campo das possibilidades do ensino e da pesquisa - e, ademais, as lutas para construir uma universidade e uma sociedade novas - são constritos ao imperativo da mercantilização, da privatização e dos valores que a presidem: a eficiência e a eficácia em face das demandas da lucratividade do capital.

A terceira afirma que, por ocuparam posição privilegiada na ordem estabelecida, as ideologias dominantes podem ditar as condições e regras gerais do próprio discurso ideológico. Sob esse guarda-chuva, consolidou-se um insidioso processo de mercantilização do ensino superior brasileiro, expresso na privatização (clássica e não clássica) e noutras medidas, que imprimem um ethos em tudo afeito a diretrizes advindas do mundo dos negócios. Qualquer contraposição é desqualificada a priori e descartada como argumento não válido. Ora, como subsistema que opera no interior da reprodução da sociedade, a educação superior e suas instituições têm de provar sua viabilidade em 
face dos imperativos (considerados supremos!) estipulados pelo sociometabolismo do capital. Daí que, como veremos, a aprovação de marcos regulatórios para o campo da produção de Ciência e Tecnologia (C\&T) guiou-se exclusivamente por supostas necessidades de injetar inovação nas empresas e, por esse meio, garantir competitividade da economia brasileira no mercado mundial.

Por seu turno, as formas de "contraconsciência" enfrentam dificuldades que derivam da sua "desvantagem posicional" em confronto com as ideologias dominantes. Trata-se de dois aspectos que as afetam desfavoravelmente, a saber:

Por um lado, em uma reação contra a pressão de se apresentar alternativas praticáveis - e a "praticabilidade" é sempre definida, é claro, a partir da perspectiva dos interesses dominantes -, elas tendem a assumir uma postura completamente negativa em relação às questões debatidas. Por outro, opondo-se à rede institucional dominante da ordem estabelecida - o odiado "sistema" -, frequentemente se recusam a vincular sua crítica a quaisquer estruturas institucionais específicas, atacando as instituições como tais e expondo-se desse modo à acusação de defender "os impulsos do individualismo anarquista. (MÉSZÁROS, 1996, p. 227)

Observa-se que a primeira dificuldade das ideologias críticas reside em que elas são obrigadas a confrontar a "praticabilidade" imposta pelos interesses dominantes e, por isso, tendem a assumir uma postura de negação absoluta do status quo e da pauta estabelecida pelos dominadores. A segunda dificuldade é que a oposição ao "sistema" resulta, frequentemente, na negação da institucionalidade como tal e, portanto, na rejeição de qualquer vínculo da crítica proferida com instituições específicas. Em ambos os casos, as "formas de contraconsciência" parecem esbarrar na impossibilidade de intervir, de modo consequente, na realidade que pretende transformar.

As desvantagens aludidas não impedem, porém, que a crítica seja veiculada e desempenhe função transformadora real. Para isso, todavia, a crítica radical das estruturas e instituições vigentes tem de ir além da negatividade absoluta, formulando uma estratégia "praticamente factível", que deve constituir o quadro de referência positiva da ação transformadora. Nesse caso, o conjunto de diretivas cravadas no Caderno 2 do Sindicato Nacional, e em vários outros documentos, expressam uma conquista de inestimável valor: a postulação do horizonte a ser conquistado, ou a 
estratégia, e a indicação das táticas a serem implementadas na luta dos movimentos sindical e social, tendo por finalidade materializar tal conquista. Construído coletivamente, amplamente discutido e votado em sua instância máxima de deliberação o Congresso do Sindicato -, o documento expressa uma crítica contundente ao ensino superior brasileiro, sem se perder na negação absoluta.

Por suposto, a crítica só tem consequência quando assumida por sujeitos coletivos que direta ou mediadamente se relacionam com as forças que disputam o controle do metabolismo social. Ainda na perspectiva meszariana, ela só ganha efetividade se articulada com um "agente social em relação ao qual é possível vislumbrar uma alternativa estrutural à ordem social dada". Como efeito,

[...] as negações radicais da ordem social dominante não podem se libertar da dependência do objeto negado e do poder da ideologia dominante com que tentam competir, a menos que possam indicar uma força hegemônica potencial historicamente identificável como sua base de suporte. (MÉSZAROS, 1996, p. 228)

Mesmo com a diferença de escopo quanto ao objeto de discussão, pois as formulações do eminente filósofo dirigem-se à totalidade do sociometabolismo, consideramos suas reflexões por demais adequadas para a análise da questão em lide neste trabalho - a situação do ensino superior no país e os imperativos de transformá-lo, perspectivando o projeto de universidade assumido pelo ANDES-SN. Trata-se, pois, de evitar a negatividade absoluta do projeto e identificar/forjar os agentes sociais capazes de empunhá-lo no âmbito das comunidades acadêmicas e no interior do conflito que se desdobra na sociedade.

Em palavras diferentes, o desafio é encontrar as possibilidades concretas de implementação da crítica radical e urdir a força social capaz de encarná-la e materializá-la em sua práxis. Isso remete à necessidade do estabelecimento de táticas (os planos de lutas do Sindicato) e de ações que produzam hegemonia em duas direções: para o interior das comunidades acadêmicas e para os sujeitos sociais externos que, incrustados no conflito social, sejam potencialmente capazes de assumir a transformação estrutural da educação superior, rumo ao projeto alternativo formulado pelo ANDES-SN. É uma tarefa de grande magnitude que tem de se efetivar num terreno hegemonizado pelo 
ethos do capital, que se apossou do centro nervoso das instituições de ensino superior no país. É o que se procura demonstrar na próxima seção.

\section{A universalização da forma mercadoria como processo inerente à reprodução do capital}

O território dos direitos sociais e dos bens públicos vem sendo devassado pela lógica mercantil, tornando-se nicho mercadológico muitíssimo interessante para o investimento privado. Ocorre, nessa seara, processo similar ao que David Harvey (2006) descreveu como ajuste espacial, perscrutando as indicações de Marx, como sendo um

[...] impulso dentro do capitalismo para criar o mercado mundial, para intensificar o volume de troca, para produzir novas necessidades e novos tipos de produtos, para implantar novos recursos produtivos em novas regiões, e para colocar toda a mão-de-obra, em todos os lugares, sob a dominação do capital. (HARVEY, 2006, p. 117)

Um dos motivos desse incessante ajuste espacial deriva da tendência à superacumulação, que exige o constante avanço do capital sobre áreas geográficas cada vez mais amplas, com o objetivo de escoar forças produtivas e criar novos mercados ${ }^{3}$. Ora, nas circunstâncias históricas da crise da economia mundial, que se arrasta desde os anos 1970, o capital viu-se diante da necessidade de combinar a abertura de novas fronteiras de acumulação (Ásia, América Latina, África Subsaariana) com o desmantelamento de sistemas protetivos ligados ao trabalho, como os sistemas previdenciários, e o conjunto de políticas públicas de assistência aos cidadãos. Esses direitos são arrancados da condição de bens públicos garantidos pelo Estado e transformados em serviços exploráveis pelo mercado. Essa colonização do território dos

\footnotetext{
${ }^{3} \mathrm{O}$ ajuste espacial, segundo Harvey, deriva da inevitável crise de superacumulação inerente ao capitalismo, "definida como excesso de capital em relação às oportunidades de empregar esse capital rentavelmente. Esse excesso de capital pode existir como excedente de mercadorias, de moeda, de capacidade produtiva, e também leva a um excedente de força de trabalho (desemprego ou subemprego amplo). A única solução efetiva para tais crises, na ausência do ajuste espacial, é a desvalorização do capital, como moeda (por meio da inflação), como mercadoria (por meio da superabundância no mercado e dos preços em queda), como capacidade produtiva (por meio de instalações, equipamentos, infraestruturas físicas etc. ociosos ou subutilizados, culminando em falência), e a desvalorização da força de trabalho (por meio e decrescentes padrões reais de vida do trabalhador)." (HARVEY, 2006, p. 114-115).
} 
direitos e políticas públicas responde à mesma voraz busca de novos espaços de acumulação de capital${ }^{4}$.

Surpreendente para parte do pensamento crítico contemporâneo, esse é, todavia, o curso natural da reprodução do capital, que tende a subjugar todas as atividades vitais da sociedade aos imperativos econômicos, orientados para a maximização dos lucros privados5. Como efeito, afirma Mészáros (2002, p. 96), o capital não é simplesmente uma entidade material restrita à esfera econômica, mas "uma poderosa [...] estrutura 'totalizadora' de controle à qual tudo o mais, inclusive seres humanos, deve se ajustar, e assim provar sua 'viabilidade produtiva', ou perecer, caso não consiga se adaptar”. Essa estrutura globalmente dominante, continua o autor,

[...] sujeita cegamente aos mesmos imperativos a questão da saúde e a do comércio, a educação e a agricultura, a arte e a indústria manufatureira, que implacavelmente sobrepõe a tudo seus próprios critérios de viabilidade, desde as menores unidades de seu 'microcosmo' até as mais gigantescas empresas transnacionais, desde as mais íntimas relações pessoais aos mais complexos processos de tomada de decisão dos vastos monopólios industriais, sempre a favor dos fortes e contra os fracos. (MÉSZÁROS, 2002, p. 96)

$\mathrm{Na}$ imediatidade, essa estrutura totalizadora - o capital enquanto relação social ganha a aparência de algo dado, inexorável e imutável. Trata-se, porém, de um conjunto de relações sociais que resultam do conflito das classes incrustadas na estrutura da sociedade. Todavia, embora o metabolismo do capital assuma a forma de uma segunda

\footnotetext{
${ }^{4}$ A professora Sara Granemann vem pesquisando essa invasão do território dos direitos sociais pela lógica mercantil como necessidade do padrão de acumulação financeirizado. É dela a seguinte passagem: "As necessidades de a acumulação capitalista encontrar novos espaços de valorização para 'resolver', ainda que momentaneamente sua crise, têm nas contrareformas do Estado a sua expressão atual. Primeiro, pela privatização das empresas produtoras de mercadorias (no Brasil importante exemplo está na siderurgia, na produção de aço) e prestadoras de serviços (dentre outros, telefonia, água, gás, bancos); segundo, pela apropriação dos espaços até então ocupados pelas políticas sociais (previdência, saúde, educação, cultura, esportes, habitação etc.) convertidos eles mesmos em serviços-mercadoria e transmutados em negócios operados pela 'iniciativa privada'; vale dizer, mercadejáveis como todas as demais mercadorias, sirvam elas ao 'estômago ou à fantasia'." (GRANEMANN, 2007, p. 60).

${ }^{5}$ Cf. Teixeira (1995, p. 57): "O mercado passa a se constituir, assim, num elo de ligação entre as diferentes atividades. Nele, e por meio dele, se tece a integração social, gesta-se a unidade do todo social. Por isso, a produção e a distribuição da riqueza social passam por um processo de coisificação, que não obedece mais a uma orientação consciente dos produtores como era nas formas de produção anteriores, onde a produção era levada a cabo de acordo com as necessidades previamente determinadas pela comunidade. A produção e a distribuição da riqueza se autonomizam perante os indivíduos, passando a se regerem por leis independentes da vontade pessoal, da política etc.".
} 
natureza, operando como uma lógica automática às costas dos indivíduos, ele tem como esteio as ações desses mesmos indivíduos inseridos no antagonismo estrutural e no conflito que se desdobra na sociedade entre as classes fundamentais ${ }^{6}$. Assim, a dominação que se imiscui nos modos de vida e a exploração que sustém as relações sociais de produção, no capitalismo, expressam interesses particulares, vinculados à classe e aos estratos de classe que personificam o capital. Não por outro motivo, no Manifesto comunista, Marx e Engels (s/d) referem-se ao avanço do capitalismo sobre as nações não como uma “dominação sem sujeito", senão como resultado do protagonismo revolucionário da classe burguesa. Afirmam os autores que, em sua ascensão na Inglaterra dos séculos XVII e XVIII, a burguesia "dilacerou sem piedade" todas as relações feudais e afogou

na água fria do cálculo egoísta todo fervor próprio do fanatismo religioso, do entusiasmo cavalheiresco e do sentimentalismo pequenoburguês. Dissolveu a dignidade pessoal no valor de troca e substituiu as muitas liberdades, conquistadas e decretadas, por uma determinada liberdade, a de comércio. (MARX; ENGELS, 2008, p. 14)

Na seção II do livro 1 de O Capital, Marx desdobra a dialética por meio da qual o dinheiro se transforma em capital, instaurando uma dinâmica automática em que o dinheiro se transforma em mercadoria para, depois, retornar à condição de dinheiro aumentado. No interior desse circuito, expresso na fórmula $D-M-D$ ', os indivíduos são personificações das forças que atuam no processo: o trabalho e o capital. Assim, os trabalhadores encarnam o trabalho e têm como função dar vida ao monstro que se lhes confronta como capital, por meio da materialização da potência capaz de criar valor e mais valor - a força de trabalho. A classe trabalhadora é, pois, um sujeito inserido no sociometabolismo como força contraditória, pois, por um lado, é a responsável pelas

\footnotetext{
${ }^{6}$ Essa forma de colocar a questão da reprodução social dá origem a muitos erros: ora se atribui poder absoluto ao indivíduo cujas ações são mediadas pela consciência e, portanto, pela decisão, ora se nega qualquer força a este, reduzindo-o a objeto passivo da dinâmica social. Também neste problema, a abordagem de Györg Lukács é crucial para se restabelecer o tertium datur desta relação. No capítulo do "Para uma ontologia..." dedicado à categoria da "reprodução social", afirma: "[...] se a reprodução social, em última análise, se realiza nas ações dos indivíduos - no imediato a realidade social se manifesta no indivíduo -, todavia estas ações, para se realizarem, se inserem, por força das coisas, em complexos relacionais entre homens os quais, uma vez formados, possuem uma determinada dinâmica própria, isto é, não só existem, se reproduzem, operam na sociedade independentemente da consciência do indivíduo, mas fornecem também impulsos mais ou menos, direta ou indiretamente, determinantes à decisão alternativa." (LUKÁCS, 1981, p. 156).
} 
bases de valorização do capital (é a força de trabalho quem cria valor excedente!) e, simultaneamente, é uma força que, ao buscar se afirmar, atua negando o capital.

A burguesia, por seu turno, só pode existir como personificação do processo objetivo de transformação do dinheiro em capital. Em consequência, cada capitalista tem de assumir a acumulação do capital como objetivo seu, como motivo de sua ação na vida econômica. Ao adiantar seu capital para a produção de mercadorias, ele não tem como meta o valor de uso, mas o valor de troca e por meio deste a obtenção de lucros; e os lucros só se obtêm no interior do incessante processo que leva o dinheiro a transformarse em mais dinheiro, a valorizar-se, processo que é fundado na exploração do trabalho de sua classe antagônica. Assim, o conteúdo objetivo da valorização do capital "é sua meta subjetiva, e só enquanto a apropriação crescente da riqueza abstrata é o único motivo indutor de suas operações, ele funciona como capitalista ou capital personificado.". (MARX, 1983, p. 129).

Esse esclarecimento se fez necessário para evitar o erro, muito comum, de se considerar o sociometabolismo capitalista como lógica supra classes, ou uma espécie de razão do mundo que se movimenta sem mediação com interesses materiais ou, quando muito, apenas se manifestando na ação dos sujeitos. Na perspectiva de Marx, essa lógica não apenas se manifesta por meio da ação das classes fundamentais, como se edifica e reproduz mediada por esta mesma ação e pelo conflito social entre elas estabelecido. Por esse motivo, o momento predominante no processo de incorporação continua sendo o ato, a ação, a práxis dos sujeitos individuais e coletivos, que podem, por necessidade ontológica, aquiescer ou transgredir a referida lógica. Não fosse assim, os fundadores do materialismo histórico dialético e as diversas correntes marxistas estariam laborando com a mesma perspectiva liberal para quem, se houve história e irrupções revolucionárias no passado, tudo se fez para chegar ao capitalismo - que é o ponto final de toda a história.

Para efeito do que se pretende argumentar no presente artigo, retenha-se de tudo que expusemos no presente tópico a lei segundo a qual a expansão do capital se processa lastreada na universalização das relações de trocas mercantis. Assim sendo, é da própria natureza do capital a tendência a transformar em mercadoria todos os espaços de vida, todas as atividades e produtos da mão humana, bem como a própria terra. 


\section{Padrão de acumulação de capital e espraiamento da lógica mercantil para a educação superior no Brasil atual}

A intrusão da lógica empresarial-mercantil no ensino superior brasileiro ocorre pela porta da frente, mas também pela dos fundos e pelas janelas. $O$ primeiro modus operandi, para tanto, dimana da natureza expansionista do capital que guarda a falsa impressão de processo inexorável que se desdobra naturalmente às costas dos poderes instituídos. Ao contrário dessa crença, Karl Polanyi demonstrou com muita precisão que o Estado desempenhou papel central na implementação da ideologia liberal do laissez-faire pela qual o mercado se elevou à condição suprema de único lócus de sociabilidade. Ora, como instância abrangente de controle das sociedades divididas em classes antagônicas, o Estado nega e absorve as energias direcionadas a formas alternativas de organização e controle social e atua, decididamente, na criação de condições jurídicas, institucionais e ideológicas para o espraiamento e consolidação da referida sociabilidade mercantil. 0 vertiginoso crescimento de empresas educacionais na seara da educação superior - a entrada triunfal pela porta da frente - jamais poderia acontecer sem o concurso dos entes estatais e dos governos. Tal crescimento responde a demandas do capitalismo dependente brasileiro e segue particularidades do padrão de acumulação vigente em cada período.

Eu sua tese de doutoramento, o professor Lalo Watanabe Minto faz profícua articulação entre as particularidades da formação capitalista brasileira e a estruturação e evolução da educação. No lastro teórico deixado por Florestan Fernandes e Caio Prado Júnior, por exemplo, Minto (2011) repõe a tese de que o capitalismo brasileiro mostrou-se incapaz de incorporar as demandas sociais, a exemplo das reivindicações de acesso à educação superior, por exemplo, dos jovens que concluem o ensino médio. A educação superior ficou, pois, restrita por muito tempo às elites dominantes e a parte dos segmentos médios da sociedade brasileira. Mesmo assim, restringia-se, no essencial, ao ensino dogmático de conhecimentos já acumulados e, geralmente, trazidos de fora, com pouca ou nenhuma pesquisa em torno das questões nacionais.

No desenrolar do Nacional-Desenvolvimentismo (1930-1964), porém, houve iniciativas pontuais na criação de universidades - geralmente pela junção e articulação de escolas isoladas - e instituições de pesquisa que respondiam a parte da demanda de 
formação científica e técnica para a administração púbica, para as funções liberais e, importante!, para suprir demandas advindas do acelerado processo de urbanização e da industrialização que contou com forte indução estatal. Assim, no período que vai dos anos 1930 ao início da década de 1960, houve expansão do ensino superior, mesmo que se tenha mantido muito aquém das demandas, com presença majoritária do setor público, que se destacava na oferta de vagas em instituições universitárias. O setor privado, por seu turno, manteve participação inferior ao público no total de matrículas e, sobremaneira, naquelas ofertadas por universidades. O protagonismo estatal nesse terreno integra a estratégia mais ampla de acumulação de capital na qual o Estado jogou papel de suma importância seja como estrutura abrangente de controle social, seja como facilitador, intermediador e promotor direto dos investimentos produtivos. A esse respeito, Lalo Minto assinala:

O desenvolvimento capitalista iniciado nos anos 1930 e especialmente pujante no pós- $2^{\text {a }}$ Guerra Mundial, não ocasionou, conforme se poderia "prever", uma similar expansão da educação superior. Mas é fato inegável que houve uma resposta por parte do Estado brasileiro quanto a esse problema, expressando as tendências mais fortes das lutas de classes no período. As "federalizações" e outros mecanismos de facilitação do acesso ao nível superior fizeram com que o setor público atingisse, nos anos 1960, sua maior dimensão em comparação ao setor privado. Além disso, a maior parte das matrículas estava concentrada em universidades e, destas, a grande maioria no setor público. Com um dado importante: o ensino $100 \%$ gratuito nas instituições oficiais havia sido conquistado no início da década de 1950. (MINTO, 2011, p. 140)

O golpe militar desfechado contra o governo de João Goulart, em 1964, e o fechamento do regime político que se sucedeu forneceram as condições políticas para a implementação de reformas na educação superior, numa tentativa de adequá-la a demandas advindas da integração do país ao capital monopolista e ao imperialismo, bem como à ambição do bloco no poder de controlar ideológica e politicamente os setores mais radicais da luta social em curso - nos quais os estudantes secundaristas e universitários e setores do proletariado urbano e de trabalhadores do campo exerciam papel decisivo.

A reforma da educação superior daria a solução conservadora para demandas que advinham de diversos setores e pressionavam o poder político: da acumulação de capital 
que, junto com a crescente urbanização, requeria escolarização mais elevada de setores da classe trabalhadora e uma pequena parcela de mão de obra formada no nível superior para atividades nos setores mais dinâmicos da indústria e dos serviços; do regime político autocrático, em sua face bonapartista, que demandava gestores públicos orientados pela tecnocracia e intelectuais para as funções de direção moral e cultural da sociedade; das camadas médias e setores do proletariado que, animados pelo espírito das massivas lutas em torno das reformas de base, exigiam a universalização de acesso à educação, inclusive ao ensino superior.

A solução urdida pela ditadura foi dotar o sistema de ensino superior público de maior capacidade de absorção da demanda (pense-se na implantação do sistema de matrículas semestral e por disciplina); otimização das estruturas instaladas para o rodízio de cursos e de turmas; maior e mais eficaz controle burocrático e autoritário; fomento da pós-graduação bancada pelo Estado; e, sobretudo, abertura do setor para o investimento privado, que se espraiou rapidamente na oferta de vagas de graduação em faculdades isoladas.

No nosso entender, e seguindo as pistas de Lalo Minto, a reforma universitária da ditadura empresarial-militar brasileira conjuminava demandas do imperialismo protagonizadas por agências como a Agência dos Estados Unidos para o Desenvolvimento Internacional (USAID, da burguesia estrangeira que atuava no país por meio das multinacionais, da burguesia nacional ligada por subordinação à dinâmica internacional, de frações da burguesia de serviços que se beneficiou largamente com a abertura do filão da educação superior para seus investimentos, de estratos da intelectualidade local marcada por uma existência “à sombra do poder" e que contribuíram para consolidar na sociedade civil o projeto ditatorial. Baseado no autor, podemos sintetizar que o projeto da ditadura para o ensino superior encaixou-se perfeitamente no padrão de acumulação de capital, atuando por três vetores principais: i) formação de parte da força de trabalho para funções elevadas requeridas pelo novo surto expansionista da indústria e dos serviços no contexto de integração do país ao capital monopolista internacional; ii) formação de quadros intelectuais para as funções de gestão pública e direção política, moral e ideológica da sociedade; iii) abertura das fronteiras do ensino superior para a expansão de capitais privados. 
As inflexões operadas no padrão de acumulação da Industrialização por Substituição de Importações (ISI), no período ditatorial (1964-1985), requereram a expansão da educação superior, sobretudo de cursos de graduação oferecidos por escolas isoladas, principalmente das instituições não estatais. Em proporção muito menor, implicou também no crescimento da oferta de vagas nas instituições públicas embasadas no tripé ensino, pesquisa e extensão. Esse surto expansionista da educação superior se inverteria com as transformações econômicas e políticas que deram origem ao padrão neoliberal de acumulação de capital a partir da década de 1980. Doravante, o crescimento na oferta de matrículas públicas é rastejante e a predominância do setor privado ganha proporções inauditas.

Para efeito do que interessa nesse artigo, frisemos apenas que em face das circunstâncias postas pelos circuitos produtivos internacionais, a opção dos ditadores foi pela continuidade e fortalecimento da presença do Estado nas grandes obras infra estruturais e no fornecimento de serviços necessários à alavancagem do desenvolvimento. Dadas as circunstâncias da luta política que ameaçara realizar reformas democráticas no país nos primórdios dos anos 1960, a ditadura impulsionou a oferta de vagas na educação superior, combinando expansão nas instituições públicas e, fundamentalmente, nas privadas. A figura 1 ilustra o que aqui se afirma.

Figura 1 - Perfil da expansão do ensino superior medido pela evolução de matrículas em cursos de graduação $(1960=100 ; 1980=100 ; 2000=100)$

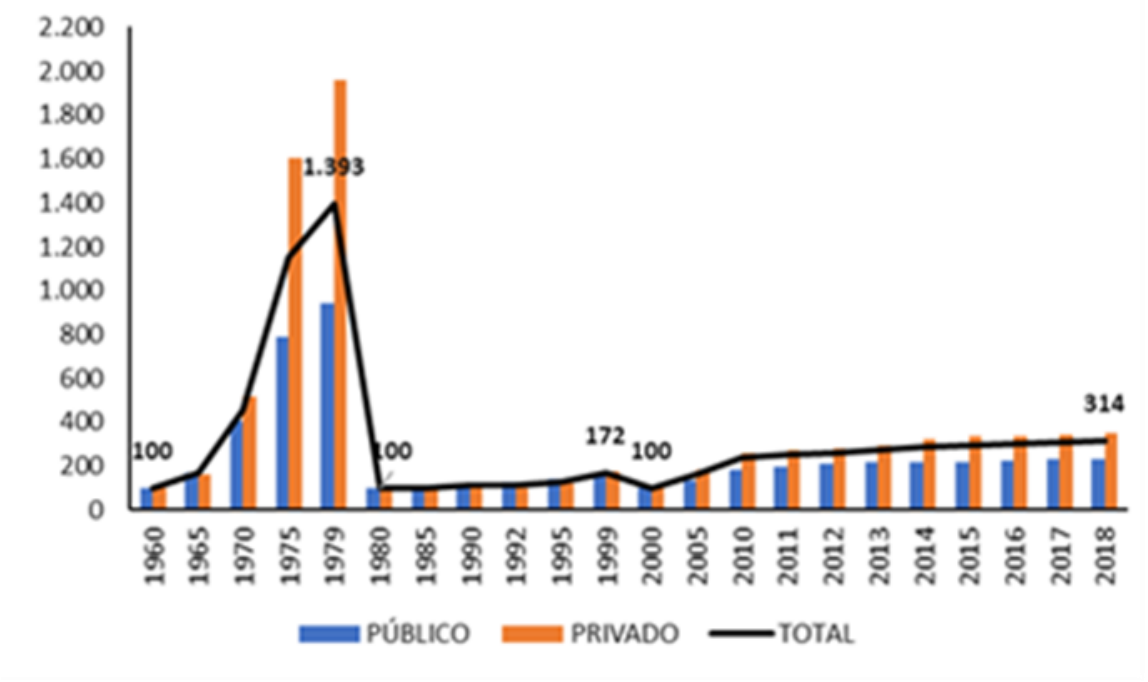

Fonte: Elaborado para este estudo a partir de dados de Sampaio (1991) e do INEP. 
A mercantilização da educação superior foi, pois, impulsionada primordialmente pela reforma da ditadura empresarial-militar que abriu as porteiras para o capital privado nesse setor. Em seu estudo, Sampaio (1991) informa que em 1955 o sistema de ensino superior brasileiro comportava 72.652 matriculados, dos quais 30.755, ou 42,33\% estavam no setor privado. Ainda segundo a autora, a prevalência do público na oferta de vagas permaneceu até o ano de 1969, pois a partir do ano seguinte o setor privado passou a contar com maior número de matrículas, conforme demonstrado na figura 2. Em seu registro fundado na particularidade brasileira, o professor Lalo Minto afirma, de modo conclusivo, que a

a privatização não é senão a forma como a educação superior brasileira foi se adequando aos projetos, determinações e perspectivas ideológicas da burguesia brasileira associada e promotora do imperialismo nas condições da particularidade. Como processo real de reprodução da educação no interior das condições do desenvolvimento capitalista, possui interesses econômicos claros, mas que, evidentemente, só se concretiza por meio de disputas políticas e ideológicas entre forças sociais concretas. (MINTO, p. 199, 2011)

Foi no fragor das disputas entre forças sociais concretas, como quer o estudioso da Universidade de Campinas (UNICAMP), e sob o tacão do regime ditatorial que o setor privado ultrapassou o público-estatal em número de matrículas, conforme ilustrado na figura 2. Doravante, a oferta de vagas e o contingente de pessoas matriculadas nas instituições não estatais progrediram cada vez mais rapidamente, enquanto o número de matriculados nas instituições estatais cresceram vegetativamente, deixando a imensa demanda por educação superior disponível à gana do mercado.

A tendência à mercantilização e à privatização desse bem social - que é a educação em todos os níveis - aprofundar-se-ia com o advento do padrão neoliberal de acumulação professado desde fins dos anos 1970 por vários organismos privados de hegemonia vinculados à burguesia brasileira. Tais organismos foram criados quando o modelo econômico e político da ditadura começou a mostrar sinais de crise já em meados dos anos 1970. Tinham por objetivo realizar estudos diagnósticos e orientar a direção da economia política doméstica pelos princípios neoliberais que grassavam nas economias de várias partes do mundo. Vários deles objetivavam, ainda, realizar mudanças 
significativas no tecido social brasileiro por meio da ideologia meritocrática, do empreendedorismo e do empresariamento de funções estatais.

O largo lapso ocorrido entre a postulação teórica do projeto, pelos ditos organismos privados de hegemonia, e sua implementação efetiva a partir dos anos 1990; os elementos progressistas cravados na Constituição de 1988, fundamentalmente no capítulo dos direitos sociais, políticos e individuais; o enraizamento da ideia de aprofundamento da democracia pela ampliação dos direitos sociais e pela participação da sociedade nos rumos políticos do país; nada disso desanimou os profetas do neoliberalismo, que insistiram nos esforços de conquista do consenso na sociedade pela função de hegemonia e do aparelho do Estado por meio de eleições ou de participação nos governos (CASIMIRO, 2018). Fato é que o professado projeto se implementa efetivamente a partir dos anos 1990, instaurando um novo padrão de acumulação de capital no país.

Onde reside a novidade do neoliberalismo? Seguimos aqui a perspectiva de estudiosos como o professor Marcelo Carcanholo (2018) para quem o projeto diz respeito a uma conformação estrutural específica da sociedade capitalista, não se definindo por uma política econômica ortodoxa como quer grande parte de especialistas no assunto, inclusive no campo crítico. Tratar-se-ia, portanto, do modo de ser do capitalismo contemporâneo que necessita realizar um conjunto de reformas estruturais cujos resultantes são, via de regra, agendas políticas e sociais extremamente regressivas. ${ }^{7}$ Para realizar tal empresa e dependendo das correlação de forças nas diversas conjunturas,

\footnotetext{
7 Saad Filho e Morais (2018, p. 97) vão na mesma direção e concebem o neoliberalismo como novo "sistema de acumulação" caracterizado por quatro especificidades: [...] a financeirização da produção, da ideologia e do Estado; a integração internacional da produção ("globalização"); um papel proeminente do capital externo na integração global da produção e na estabilização do balanço de pagamentos; e uma combinação de políticas macroeconômicas baseada em políticas fiscais e monetárias contracionistas e em metas de inflação, na qual a manipulação das taxa de juros se torna a principal ferramenta de política econômica. Em profícua análise, Décio Saes diz: "Será considerada neoliberal toda ação estatal que contribua para o desmonte das políticas de incentivo à independência econômica nacional, de promoção do bem-estar social (Welfare State), de instauração do pleno emprego (keynesianismo) e de mediação dos conflitos socioeconômicos." Esse desmonte, continua o estudioso, se processa por meio de três políticas: "A primeira delas é a política de privatização das atividades estatais: não só a desestatização de empresas públicas, geradoras de produtos industriais ou serviços pessoais como até mesmo a desestatização de atividades administrativas, tais como o serviço penitenciário, o Banco Central, a receita federal etc. A segunda delas é a política de desregulamentação: isto é, a redução da atividade reguladora e disciplinadora do Estado no terreno da economia (em geral) e das relações de trabalho (em particular). A última dessas políticas é a política de abertura da economia ao capital internacional: eliminação incondicional das reservas de mercado e do protecionismo econômico." (SAES, 2001, p. 82).
} 
esse projeto pode contar com uma política econômica mais ortodoxa ou mais heterodoxa, desde que as referidas contrarreformas sejam realizadas e a dinâmica social seja orientada pelo conservadorismo mais rebaixado ou pelo social-liberalismo que em nada fere o processo de acumulação.

Para efeito do argumento central desse estudo, assinalemos apenas que o padrão neoliberal de acumulação supõe maior liberdade e protagonismo do mercado que, ao contrário do que se popularizou sobre a emergência de um Estado mínimo, exigem maior presença do aparato estatal no desmantelamento de regulações do mercado doméstico, dos sistemas protetivos do trabalho, das organizações sindicais e populares, dos direitos sociais de natureza universal em prol de um rol de programas e políticas focalizadas. Além disso, a função coercitiva e punitiva do Estado é inflada, além de operar transformações substantivas em suas estruturas em favor do empresariamento de parte das obrigações como as de fornecimento de serviços públicos essenciais (CASIMIRO, 2018).

Ao mesmo tempo, os interesses do grande capital transnacional e de sua sócia subordinada - a burguesia doméstica - exigem a retirada do Estado dos setores estratégicos da economia por meio da privatização - o que está em razão inversa do padrão de acumulação por substituição de importações (SAAD FILHO; MORAIS, 2018) -, ou via parcerias público-privadas e por diversos outros mecanismos institucionais cuja função é impor a lógica empresarial e privatista sobre a coisa pública e gestão estatal e/ou carrear fundos públicos para subsidiar a acumulação privada. A forte presença do Estado foi também requerida para o propósito de reconstruir o poder das elites dominantes conforme assinala David Harvey (2008) em se tratando da neoliberalização do mundo.

No plano doméstico, as políticas estatais se empenharam na criação de mecanismos que levariam à financeirização da economia ao ponto de, segundo registro de Leda Paulani (2008), o país ter se convertido à servidão financeira. Tais políticas impactaram negativamente na participação da indústria na composição do Produto Nacional Bruto (PIB), inflando o setor de serviços e financeiro. Ao mesmo tempo, seguindo a tradição da burguesia brasileira de investir pensando em lucros fáceis e de curto prazo, os esforços estatais se direcionaram pela lei das "vantagens comparativas", impulsionando a produção de bens primários, descuidando e desaconselhando qualquer iniciativa que visasse a diminuição da distância científica e técnica do país em relação aos 
centros sistêmicos (Estados Unidos, União Europeia e Japão). Tratou-se do consenso das commodities que teria se seguido ao consenso de Washington, segundo afirma Maristela Svampa (2017).

Assim, mesmo quando o padrão de acumulação neoliberal teve de ser ajustado no fim do primeiro quinquênio dos anos 2000 - de um lado, por causa da crise econômicosocial e do desgaste político que enfrentava em vários países latino-americanos e, de outra banda, pela formação de um novo bloco político assentado na conciliação entre classes antagônicas e frações internas da burguesia local -, os governos progressistas de Lula da Silva e de Dilma Rousseff deram continuidade a todas as principais pilastras do referido padrão de acumulação. Tais governos expressaram a reacomodação, no bloco no poder, das classes capitalista e trabalhadora.

A esse respeito, Luiz Filgueiras (2018, p. 531) informa que em todo o período neoliberal houve hegemonia dos financistas sobre outras frações que participavam do bloco no poder como o "capital exportador - indústria extrativa mineral e agronegócio”. Porém, na virada do primeiro para o segundo mandato de Lula da Silva, a correlação de forças se alterou, pois "cresceram em importância outras frações do capital, como as grandes empreiteiras e as grandes redes de comércio varejista - na esteira da retomada dos investimentos do Estado e de uma política econômica de estímulo ao consumo.". Além, é óbvio, do envolvimento de parte importante do movimento sindical e popular na administração estatal ou como suporte direto do governo, que era uma novidade na administração de um pequeno período da autocracia institucionalizada brasileira.

Em sua atual fase, o padrão neoliberal de acumulação de capital reserva para o ensino superior funções e institucionalidades específicas que, por suposto, são diferentes do que se apresentava no período desenvolvimentista, seja sob regimes políticos democráticos ou ditatoriais. Se, como assinalamos com base no estudo de Lalo Minto, o nacional-desenvolvimentismo alimentou as utopias de democratização da educação e fortalecimento do ensino superior como elementos basilares do desenvolvimento da nação, as escolhas da burguesia brasileira na passagem da ditadura para o regime civil foram em sentido diverso. Tratava-se, isto sim, de desregular esse bem social, criar nova institucionalidade sobre o mesmo, com o fim de abri-lo ao investimento do empresariado de serviços educacionais com amplo subsídio público -, este último foi amplamente 
utilizado pelos governos progressistas de Lula da Silva e Dilma Rousseff. Daí que a evolução do público e do privado se dão de forma bastante assimétricas como se demonstra na figura 2 .

Figura 2 - Evolução de matrículas em cursos de graduação presenciais por categoria administrativa - Brasil - anos selecionados

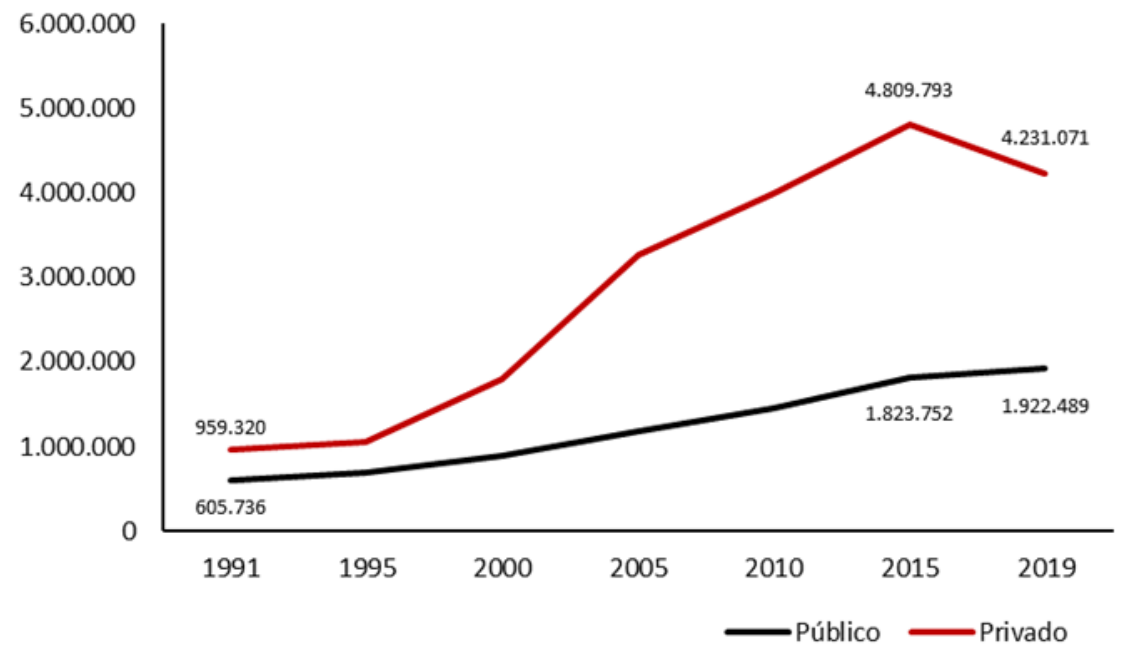

Fonte: INEP. Elaborado pelo autor, 2021.

A estratégia de abertura da educação superior como filão para investimentos lucrativos privados cumpre, primeiramente, a função de criar espaços de acumulação, realizando nesse território o que David Harvey expõe sob a categoria de "ajuste espacial"8. Sob forças limitantes da migração de capitais dos centros para as periferias, que fora a principal estratégia para empurrar para a frente as contradições causadoras da grande depressão dos anos 1930, desde pelo menos quarenta anos o capital se vê obrigado a racionalizar e potencializar os mercados existentes. Combinam-se, hoje, a exportação de capitais e o desmonte de barreiras nacionais - mormente nos países

\footnotetext{
8 Harvey (2006, p. 118): "O desenvolvimento desimpedido do capitalismo em novas regiões é uma necessidade absoluta para a sobrevivência do capitalismo. Essas novas regiões são os lugares onde o excesso de capitais superacumulados podem mais facilmente ser absorvidos, criando novos mercados e novas oportunidades para investimentos rentáveis." Essa dinâmica expansionista para todos os territórios possíveis é uma necessidade posta por uma das contradições do capital: a de produzir mais produtos e forças produtivas do que mercados capazes de absorvê-las, o que conduz à superacumulação. Não é, porém, uma estratégia suficiente para barrar as crises, como o próprio geógrafo britânico reconhece em seu livro.
} 
periféricos - com a taxa de uso decrescente das mercadorias e dos bens de capital ${ }^{9}$ e a devastação das regulações que garantiam territórios de direitos e bens sociais, inclusive aqueles relacionados à produção e reprodução da força de trabalho ${ }^{10}$. Ora, eram esses territórios dos bens sociais que pareciam imunes à lógica mercantil que hoje são tragados por essa lógica, tornando-se espaço de acumulação. A figura 3 apresenta, em síntese, o estado atual do avanço do mercado sobre o setor.

Figura 3 - Número de Instituições de Ensino Superior (IES) e de matrículas em cursos de graduação, por organização acadêmica e categoria administrativa - Brasil, 2018

\begin{tabular}{|c|c|c|c|c|c|c|c|c|c|c|c|c|}
\hline \multirow{3}{*}{$\begin{array}{c}\text { ORGANIZAÇĀO } \\
\text { ACADËMICA } \\
\text { UnIversl dades }\end{array}$} & \multicolumn{6}{|c|}{ INSTI TUIÇŌES } & \multicolumn{6}{|c|}{ MATRICULAS } \\
\hline & \multicolumn{2}{|c|}{ TOTAL } & \multicolumn{2}{|c|}{ PÜBUCO } & \multicolumn{2}{|c|}{ PRIVADO } & \multicolumn{4}{|c|}{ PÜBLICO } & \multicolumn{2}{|c|}{ PRIVADO } \\
\hline & 199 & $100 \%:$ & 107 & $53,77 \%$ & 92 & $46,23 \%$ & 4.467 .694 & $100 \%$ & 1.735 .000 & $38,83 \%$ & 2.732 .694 & $61,17 \%$ \\
\hline Centros Unlvers Itários & 230 & $100 \%$ & 13 & $5,65 \%$ & 217 & $94,35 \%$ & 1.906 .327 & $100 \%$ & 23.851 & $1,25 \%$ & 1.882 .476 & $98,75 \%$ \\
\hline Faculdades & 2.068 & $100 \%:$ & 139 & $6,72 \%$ & 1.929 & $93,28 \%$ & 1.879 .228 & $100 \%$ & 121.124 & $6,45 \%$ & 1.758 .104 & $93,55 \%$ \\
\hline IF E CEFET & 40 & $100 \%:$ & 40 & $100,00 \%$ & 0 & $0,00 \%$ & 197.506 & $100 \%$ & 197.506 & $100,00 \%$ & 0 & $0,00 \%$ \\
\hline$\Sigma$ & \multicolumn{2}{|c|}{2.537} & \multicolumn{2}{|c|}{299} & \multicolumn{2}{|c|}{2.238} & \multicolumn{2}{|c|}{8.450 .755} & \multicolumn{2}{|c|}{2.077 .481} & \multicolumn{2}{|c|}{6.373 .274} \\
\hline$\%$ & \multicolumn{2}{|c|}{$100 \%$} & \multicolumn{2}{|c|}{$11,79 \%$} & \multicolumn{2}{|c|}{$88,21 \%$} & $100 \%$ & & \multicolumn{2}{|c|}{$24,58 \%$} & \multicolumn{2}{|c|}{$75,42 \%$} \\
\hline
\end{tabular}

Fonte: INEP. Elaborado pelo autor, 2021.

Os dados sinalizam elementos de natureza qualitativa, porquanto vale observar que dos mais de 8,4 milhões de matriculados, cerca de 4,5 milhões (53\%) frequentam instituição universitária. O setor privado açambarca 6,3 milhões de matriculados dos quais pouco mais de 2,7 milhões (43\%) se encontram em universidades e o restante, $57 \%$, frequenta instituições não universitárias. No setor público, $84 \%$ dos estudantes estão matriculados em instituições universitárias e 16\% em instituições não universitárias. O mesmo censo de 2018 indica que das funções docentes ativas no setor público, 64\% tem titulação de doutor e $34 \%$ de mestre e especialista; no setor privado, o percentual é de $26 \%$ e $74 \%$, respectivamente. Isso indica que a tendência inaugurada pela reforma

\footnotetext{
9 Mészáros (2002), principalmente cap. 14, 15 e 16. A obsolescência planejada é uma das principais estratégias do capital para fazer frente à contradição existente entre a quantidade de forças produtivas e de mercadorias e a incapacidade de absorção pelos mercados viáveis.

10 Oliveira (1998). Sob nosso olhar, o otimismo do velho mestre quanto à hipertrofia do território dos direitos (o anti-valor) e ao soerguimento de uma esfera pública na qual as classes administrassem seus conflitos e resolvessem a apropriação e alocação do fundo público não se materializaram. A resolução tem sido exclusivamente pelas forças do capital que tem avançado vorazmente sobre esses territórios. Uma apropriação crítica do inestimável contributo de Francisco de Oliveira e um mas allá analisando o fundo público e várias políticas sociais encontram-se em Salvador, Behring e Lima (2019).
} 
universitária da ditadura empresarial-militar, assinalada com base em Minto (2011), recrudesceu no decorrer dos governos civis: a massificação da educação superior deu-se pela via privada prioritariamente em instituições não universitárias que contam com grande maioria dos docentes com titulação de especialista e mestre. É importante, porém, perguntar sobre a evolução de matrículas na modalidade de ensino presencial e a distância. A figura 4 tem o objetivo de ilustrar essa informação.

Figura 4 - Tendência evolutiva do total de matrículas em cursos de graduação por modalidade de ensino - Brasil (2006=100)

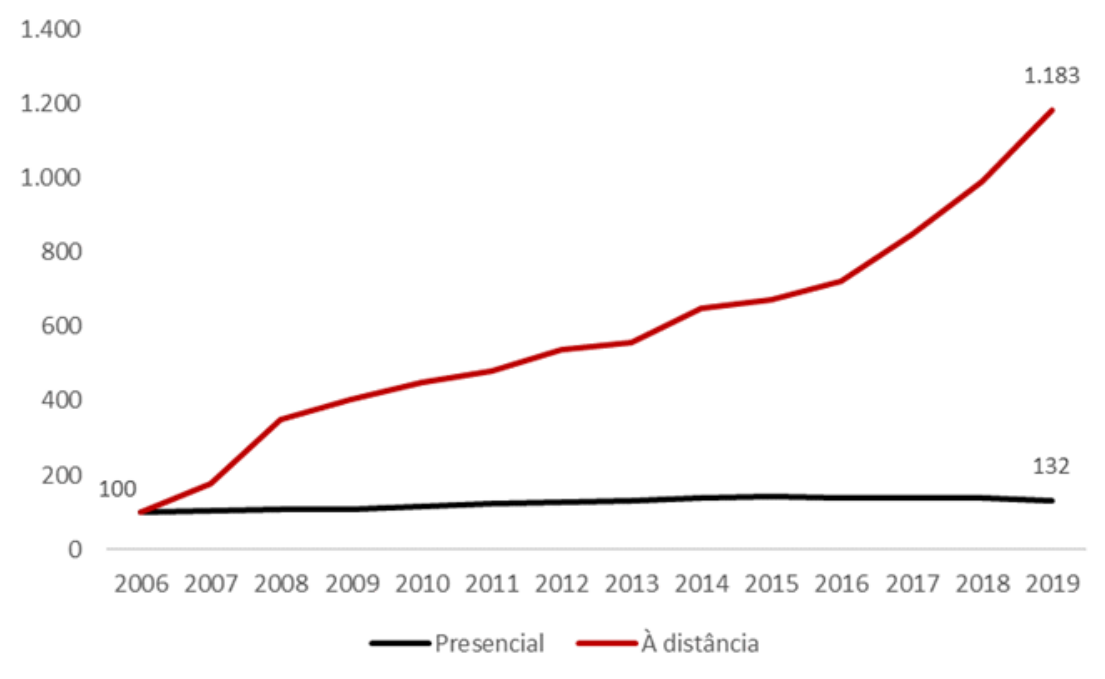

Fonte: INEP. Elaboração do autor, 2021.

Na mesma medida em que a lógica empresarial avança sobre o ensino superior no país, ela também transforma, por força das coisas, a natureza, a institucionalidade e função desse bem social que deveria ser público. Orientados pela maximização dos lucros, tais investimentos necessitam repor formas antigas e combinar com novas maneiras de explorar mais sobretrabalho dos docentes e aumentar a produtividade - que nesse caso deve ser medida pela quantidade de pessoas formadas no menor tempo e com a menor despesa possível. Sobrevêm, pois, o nivelamento por baixo dos salários dos professores e de outros profissionais, a contratação de docentes com titulação acadêmica mediana (especialização e mestrado), a intensificação do trabalho e aumento do número de alunos por docente, o enxugamento das grades curriculares e o 
encurtamento do tempo dos cursos de graduação e pós-graduação. Eis que, consoante com a lógica dos lucros privados, a expansão da oferta de matrículas tem se dado, prioritariamente e como linha de tendência, na modalidade Educação à Distância (EaD) em detrimento da modalidade presencial.

A figura 4 permite afirmar que está em curso uma vertiginosa expansão da oferta de matrículas pela via da EaD. Comparando com a figura 2, é possível dizer, ainda, que está em processo a substituição do ensino presencial na inciativa privada pela EaD. Com efeito, o número de matrículas em cursos presenciais nas IES privadas caiu seguidamente desde 2015, queda que vem sendo compensada pelo crescimento de matrículas na modalidade à distância. Do total de 2,4 milhões de matrículas ofertadas na modalidade à distância, 94\% (2,3 milhões) estão na iniciativa privada e apenas 6\% (157,6 mil) são ofertadas pelas IES públicas, segundo o censo realizado pelo INEP referente ao ano de 2019.

A tendência assinalada tem suas causas mais profundas no crescimento do desemprego e no rebaixamento dos rendimentos dos trabalhadores, cujas perdas se aprofundaram com a crise econômica que assola o país e com o conjunto de contrarreformas (lei da terceirização, reforma trabalhista, reforma previdenciária e EC 95 fundamentalmente) que impõem padrões mais rebaixados do uso da força de trabalho esta que responde por quase a totalidade da demanda das IES privadas. Encontra-se, dessa maneira, outro liame entre o padrão neoliberal de acumulação e a educação superior, no caso elementos restritivos de demanda aos quais as empresas respondem do seu modo particular: procurando ofertar um serviço de custo mais baixo, mais adequado às oscilações de tempo e de espaço na vida dos trabalhadores, o que implica numa formação muito mais precarizada do que aquela que se dá presencialmente.

A formação rebaixada destinada à ampla massa de estudantes matriculados principalmente nas instituições privadas é, ainda, funcional ao padrão neoliberal de acumulação porque, além de representar um filão para investimentos represados, forma a mão de obra para a imensa maioria dos postos de trabalho posicionados na base da pirâmide salarial, sejam formais ou informais. Tem, ademais, função ideológica específica: desencadear processos de subjetivação orientados por parâmetros como a liberdade 
individual desconectada do pertencimento de classe e avessa à ideia de justiça social ${ }^{11}$;

fomentar o empreendedorismo e legitimar toda sorte de medidas que tencionam comprimir os salários diretos e indiretos dos trabalhadores. Esses potentes discursos ideológicos e a desregulamentação promovida pelo Estado exercem papel decisivo na conformação da consciência na direção do ajustamento dos trabalhadores aos imperativos da crise estrutural que, hoje, transforma grande parte da força de trabalho disponível em mercadoria supérflua ${ }^{12}$. A massificação da educação superior por via privada, com tendência a substituir ensino presencial por ensino à distância, é, pois, amplamente favorável ao padrão neoliberal de acumulação de capital.

Resta, ainda, registrar que a privatização ocorre pelas vias demonstradas - de transformação do bem social em mercadoria -, mas também por meio de mecanismos institucionais diversos. A professora Sara Granemann é precisa quanto a isso ao classificar as privatizações em dois tipos, clássicas e não clássicas. Diz a pesquisadora:

Clasicas: consisten en la venta y alienación del fondo público definitiva o provisoriamente (en el caso de las concesiones) con entrega de patrimônio. No clasicas: implica la venta y/o entrega de recursos patrimoniales mas sofisticados bajo la forma de diferentes entes jurídicoadministrativos que se pretenden ejecutores de "políticas sociales". (GRANEMANN, 2017, p. 238)

\footnotetext{
${ }^{11}$ Harvey (2014) para quem o neoliberalismo obteve audiência, em parte, por falar de um princípio muito caro às gerações atuais: o princípio da liberdade. Ocorre que tal princípio é referido exclusivamente ao indivíduo muitas vezes em confronto com a lei social, com a ideia de coesão e pertencimento social. Uma leitura psicanalítica desse aspecto é oferecida por Nelson da Silva Júnior ao afirmar que "Há um sujeito que foi produzido especificamente pela formação discursiva neoliberal, com suas formas de verdade, seus valores morais, suas instituições sociais. Nesse sujeito, continua o estudioso, uma ideia precisa de liberdade está presente, a saber, a liberdade se não como independência comportamental, pelo menos como não submissão moral do indivíduo às normas sociais." O negacionismo da ciência e da vacina contra a Covid-19 está aí para ilustrar como esse tipo de conduta moral que se arvora o direito de desconsiderar a norma social, em nome da liberdade, ganhou audiência e se incrustou nos processos de subjetivação desencadeados pelas transformações exigidas pelo padrão neoliberal de acumulação de capital. Encontrase, dessa forma, outros liames entre estruturas econômicas e sociais, ideologias e conduta moral.

${ }^{12}$ Mészáros (2002, p. 342): "Hoje estamos testemunhando um ataque em duas frentes à classe operária, não apenas nas partes 'subdesenvolvidas' do mundo, mas também, com implicações perigosas para a viabilidade continuada do modo estabelecido de reprodução sociometabólica, nos países capitalistas avançados. Estamos testemunhando: 1) um desemprego que cresce cronicamente em todos os campos de atividade, mesmo quando é disfarçado como 'práticas trabalhistas flexíveis' - um eufemismo cínico para a política deliberada de fragmentação e precarização da força de trabalho e para a máxima exploração administrável do trabalho em tempo parcial; e 2) uma redução significativa do padrão de vida até mesmo daquela parte da população trabalhadora que é necessária aos requisitos operacionais do sistema produtivo em ocupações de tempo integral."
} 
Mais adiante, a autora informa que

La experiência de la privatizacion en el mundo hizo surgir numerosas formas de privatizar: las sociedades público-privadas, las fundaciones estatales de derecho privado (FEDP), las organizaciones sociales (OS), las organizaciones de la sociedad civil de interés público (OSCIP), la empresa brasileña de servicios hospitalares (EBSEHR), la fundación de previsión complementária del servicio público federal (FUNPRESP). (GRANEMANN, 2017, p. 239)

A mercantilização constitui, pois, a entrada triunfal da lógica do capital sobre os territórios dos direitos sociais, dentre estes, o do direito à educação pública. Trata-se do cumprimento da força movente interior do capital que pretende transformar toda forma de atividade, todo direito conquistado e todo produto ou serviço em mercadoria e subordiná-los aos princípios da eficiência, eficácia e maximização de lucros privados. Mas o capital abre caminho igualmente pelas janelas, portas laterais e pela cozinha despedaçando sem piedade sistemas regulativos para se imiscuir na esfera estatal, nas instituições de interesse público, conforme pensado na reforma do Estado levantada por Bresser Pereira ${ }^{13}$, no governo de Fernando Henrique Cardoso, continuada por Lula da Silva e Dilma Rousseff e potencializada pelos governos pós-golpe de 2016. Referimo-nos à invasão da sociedade e dos aparatos estatais por entes jurídico-administrativos que se pretendem executores de políticas sociais, como assinalou Granemann (2017). Todos os mecanismos institucionais citados pela pesquisadora atuam, hoje, fortemente no interior das instituições públicas de ensino superior e muitos foram objeto de denúncia e investigação pela apropriação indevida ou desvio de recursos. Após examinar algumas fundações “ditas” de apoio a universidades públicas, Ciro T. Correia afirma que elas

[...] tornaram-se o instrumento mais eficaz para desviar das IES recursos públicos (e mesmo privados) previstos para serem a elas destinados para o financiamento de projetos de Ciência e Tecnologia - C\&T. Constituíramse também no modo mais dissimulado de colocar a capacidade intelectual instalada nas universidades a serviço dos interesses dos setores com poder econômico na sociedade para "compra-la", possibilitando a participação de docentes, pesquisadores e funcionários técnico-administrativos em projetos privados contratados e remunerados via fundações. (CORREIA, 2017, p. 137)

\footnotetext{
${ }^{13}$ Conferir a série de Cadernos MARE divulgados pelo governo e pelo seu articulador Luiz Carlos Bresser Pereira. Disponível em http://www.bresserpereira.org.br/documentos/100.
} 
Assim, além do alastramento das empresas educacionais na educação superior, retendo mais de $75 \%$ de todo o alunado como demonstrado na figura 3 , a lógica privatista invade as IES públicas pela porta dos fundos. Essa invasão não retrocedeu nenhum passo ao longo dos diversos governos e até se amplificou nos governos progressistas de Lula da Silva e de Dilma Rousseff. Os instrumentos regulatórios da C\&T, cujo tratamento sistemático realizaremos em outro estudo, são todos estruturados sobre a ideia das parcerias público-privadas entre universidades e outras instituições públicas que desenvolvem pesquisa e empresas privadas. Todos justificam a necessidade de vinculação entre a pesquisa científica, desenvolvida sobretudo nas universidades públicas, com o mercado, o que exige a infestação das IES por OS e outras personalidades jurídicas de direito privado ${ }^{14}$.

\section{4. À guisa de conclusão: desafios para a defesa da educação superior como bem social garantido pelo Estado}

Nestas linhas finais e sem pretensão de fechar o debate, arrolamos as tendências que achamos serem obstáculos ao projeto de universidade defendido pelo Andes-SN e uma série de desafios que se apresentam para as possíveis forças sociais e políticas interessadas nas instituições públicas de ensino superior, bem como no complexo público de ciência e tecnologia ( $C \& T)$.

No Brasil, a esperança de uma socialdemocracia tardia, ideologicamente motivada a recuperar a natureza social e pública do território dos direitos sociais, operou muito na solidão, isto é, desacompanhada da análise da dinâmica e das novas estruturas que conformaram o padrão neoliberal de acumulação de capital. Às vezes, essa análise era descartada por ser portadora de certo pessimismo, mas via de regra, a recusa se devia ao império do politicismo ${ }^{15}$ que predominou e predomina no pensamento e na práxis progressista no Brasil.

\footnotetext{
14 O Caderno 28 do Andes-SN é dedicado à análise das diretrizes neoliberais que informam os marcos legais de C\&T: a Lei 10.973/2004, a Emenda Constitucional 85/2015 e a Lei 13.243/2016.

15 Tomamos de empréstimo o conceito de J. Chasin em cáustica crítica da esquerda e ao analisar o que ele mesmo chamou de "A miséria brasileira". "A autonomização do político e sua consequente hiperacentuação é, de fato, seu esvaziamento numa entidade abstrata, a perda de sua concretude, e
} 
A superação, pois, do politicismo - que toma o político como totalidade e despreza as estruturas econômicas e sociais, esvaziando, assim, a própria política numa entidade abstrata, como quer J. Chasin - é uma necessidade dos dias. O esgotamento dos governos progressistas mostrou que mudanças mesmo superficiais na sociedade brasileira requerem reformas das estruturas de poder econômico e político. Mais uma vez, um episódio histórico que animou a esperança das amplas massas do povo brasileiro prova que mesmo mudanças epidérmicas, direcionadas à promoção de direitos de cidadania, exigem transformações substantivas no Brasil. Dá prova inconteste de que a tão aclamada "vontade política" é uma abstração, na medida em que ela mesma é, desde o início, a orientação, o norte, o horizonte de uma práxis informada por interesses que deitam raízes nas estruturas econômicas e sociais. Decorre que o projeto de universidade do Andes-SN vê-se confrontado não apenas com uma orientação política conservadora que é o inimigo imediatamente visível a fomentar o ódio de cariz étnico-racial, por exemplo - mas com o próprio padrão neoliberal de acumulação de capital em sua face dependente.

Imediatamente, a defesa da universidade pública socialmente referenciada mira o governo e o fundo público, pois não é possível garantir recursos para sustentar as instituições existentes e, ademais, para expandi-las sem guerrear com capitalistas e segmentos parasitários que vivem à sombra dos recursos estatais. Mesmo essa batalha por orçamentos para as IES públicas, em particular, e para as políticas sociais, em geral, confronta imediatamente o sistema tributário regressivo e o da dívida pública, bem como atinge em cheio a Emenda Constitucional 95/2016 que garroteia os gastos primários do Estado. ${ }^{16} \mathrm{~A}$ mirada aos orçamentos já requer, pois, reformas progressivas em pilastras do

\footnotetext{
decorrentemente de sua potência e eficácia. De todo modo, a politicização da totalidade pelo discurso é pelo menos um grosseiro gesto simplificador que, no mínimo, desconhece, desrespeita e/ou elimina a qualidade própria das demais componentes que integram a totalidade. Converter e diluir tais qualidades ao meramente 'político', além da bárbara arbitrariedade que subentende, é ao mesmo tempo uma condenação à impotência no plano objetivamente político, na medida que este se põe como ação, préfigurada mentalmente, que por interesse teleológico se submete à intrincada causalidade do todo. O que é o mesmo que dizer que o agente para efetivar seu fim a este se submete, subordinando-se, assim, necessariamente às propriedades e virtualidades de seu objeto. À evasão do concreto, induzida pela politicização, a verdadeira política contrapõe, pois, a si mesma como prática que toma o trabalho como protoforma" (CHASIN, 2000, p. 9). Essa perspectiva é por ele invocada em vários textos, inclusive na coletânea intitulada "A determinação ontonegativa da politicidade".

${ }^{16}$ Cf. Reis e Macário (2020). Dívida pública e financiamento das universidades federais e da ciência e tecnologia no brasil (2003-2020).
} 
padrão neoliberal de acumulação de capital que reproduzem e amplificam a financeirização da economia, a concentração de renda e patrimônio e a desigualdade social.

Vê-se, por essa via, como uma possível democratização do ensino superior com financiamento estatal passa por reestruturações muito mais profundas que subjazem o jogo das forças políticas em torno da alocação dos fundos públicos. Já por esse motivo, a ação parlamentar se mostra necessária, mas absolutamente insuficiente porque o campo decisivo da disputa está na sociedade civil e no quanto as forças que nela operam fazem cumprir seus interesses nos governos e parlamentos. O nível de organização dos sindicatos e de outros organismos da sociedade civil que personificam as forças do trabalho - isto é, as lutas contra o capital, dentre elas as que se fazem na defesa de direitos sociais, civis, políticos e humanos -, sua estratégia e táticas de lutas é que podem ter resultados na alocação dos fundos estatais em favor do povo, da universidade e do complexo público de C\&T.

Da mesma forma, as lutas contra a mercantilização e maneiras diversas de privatização da educação superior não podem cristalizar-se sob bandeiras mortas. Precisam ser dinamizadas a partir mesmo da realidade posta e, como demonstramos, o padrão neoliberal de acumulação significou, até aqui, a consolidação dos dois processos. Concretizaram-se tanto a mercantilização, que ganha impulso desde a ditadura empresarial-militar, quanto a privatização por dentro das IES públicas em decorrência da Reforma do Estado implementada por Fernando Henrique Cardoso, continuada e até expandida nos governos progressistas de Lula da Silva e Dilma Rousseff - como é o caso das OS, das fundações ditas "de apoio" e processos de terceirização que se incrustaram nas estruturas das instituições púbicas de ensino superior. Em 2018 , perto de $76 \%$ dos mais de 8,4 milhões de matriculados em cursos de graduação compravam sua formação em instituiçõos privadas; as vagas das IES públicas chegavam a aproximadamente $24 \%$ desse total. Além do mais, a estratégia da iniciativa privada tem sido a expansão vertiginosa do ensino à distância em detrimento do presencial, o que traz implicações extremamente deletérias para a qualidade desse nível educacional no país.

Argumentamos que a mercantilização é inerente ao processo de reprodução ampliada do capital e, juntamente com a privatização, constitui esteio do padrão 
neoliberal de acumulação. O sonho, pois, da social democracia de colocar peias no capital, conquistar e proteger um território crescente de direitos sociais parece ter sofrido grave derrota na era da crise estrutural do capital. Assim, nas atuais circunstâncias da realidade brasileira, a bandeira da educação superior como bem público passa pela inarredável defesa das IES públicas, é bem verdade, mas cinge-se, fundamentalmente, a um projeto de desenvolvimento econômico, social e cultural autônomo do país no qual esse nível educacional esteja a serviço do conhecimento e da solução dos problemas vividos pela maioria do povo. Uma luta dessa envergadura exige ingentes esforços dos setores organizados das comunidades acadêmicas - nas IES públicas e privadas - mas desborda necessariamente esse âmbito e precisa incorporar forças sociais que atuam no conflito que se desdobra entre as classes fundamentais.

Conforme apontamos no início deste estudo, as formas de contra-consciência ou as ideologias críticas só podem ter consequência se vinculadas e operadas por forças sociais reais, incrustadas na sociedade civil. Têm que superar a mera negação absoluta do quadro posto, pois tal negatividade sabe apenas apontar o fim sem qualquer apreço pelas mediações efetivas, práticas, para materializá-lo. Quedam, portanto, inócuas e praticamente inoperantes em face do quadro posto. Essas mesmas ideologias têm de apontar o fim que contradita a realidade posta como alternativa abrangente - no caso em estudo, o projeto de universidade do Andes-SN - mas sempre ancorada em agentes sociais reais que se vinculam, por diversas mediações, às forças que disputam com o capital o controle do sociometabolismo.

Isso implica que a defesa da educação superior como bem público, a ser arrancado ao Estado e por ele garantido, tem de ser assumida por determinados grupos de interesses que, seguramente, não são os da burguesia brasileira, nem tampouco de determinados estratos endinheirados da elite. Sob o padrão neoliberal de acumulação, a burguesia brasileira não necessita nem nutre qualquer interesse pela universidade pública de qualidade, pois a mão de obra de que necessita já é fornecida - em termos quantitativos, técnicos e ideológicos - pela massificação do ensino superior privado. E sua própria formação acadêmica, como estrato social, pode ser realizada nas poucas IES públicas existentes, ou em instituições privadas ditas de excelência, nacionais e internacionais. Esses estratos sociais, que conjuminam a grande burguesia, a pequena 
burguesia doméstica e uma faixa de segmentos endinheirados, são a perfeita personificação da subordinação estrutural do país no gradiente da divisão internacional do trabalho; por essa razão orientam sua existência pelo cosmopolitismo de cócoras em detrimento da valorização da nação e do povo brasileiro - de onde retiram toda a base material de sua riqueza. Não é possível, pois, contar com estes sujeitos sociais na defesa do projeto de universidade empalmado pelo Andes-SN.

Nas condições da crise atual do padrão neoliberal de acumulação, somente as forças sociais orientadas pela lógica unificadora do trabalho podem assumir a defesa política da educação superior pública e de qualidade. Pelo lugar que ocupam na estrutura econômica e social - que lhes impõe como destino a superexploração, as carências de recursos básicos de existência digna, as opressões de matriz étnico-racial e o preconceito enraizado na questão de gênero e sexual - os segmentos e categorias da classe trabalhadora constituem uma contradição em-si, uma negação em-si, do capital. O esforço deve ser, pois, pelo desencadeamento de lutas sociais que, partindo das pautas imediatas desses segmentos do povo trabalhador, operem a passagem do em-si ao parasi, que consigam envolver as pautas imediatas, corporativas e identitárias - que foram atualizadas de maneira dramática na atual crise do neoliberalismo, pelo avanço do conservadorismo e do autoritarismo - a lutas mais gerais que mirem o horizonte das transformações das estruturas econômicas, sociais e políticas do país. 
ANDES-SN. Neoliberalismo e política de c\&t no Brasil - um balanço crítico (1995-2016). caderno 28. $1^{\text {a }}$ ed. Brasília: ANDES-SN, 2018.

ANDES-SN. Proposta do ANDES-SN para a universidade brasileira: caderno $2,4^{\mathrm{a}}$ ed. atualizada e revisada. Brasília: ANDES-SN, 2013.

BRASIL. INSTITUTO NACIONAL DE ESTUDOS E PESQUISAS EDUCACIONAIS - INEP.

Evolução do ensino superior - graduação 1980-1998. Brasília: INEP, 1999. Disponível em http://download.inep.gov.br/download/censo/1998/superior/evolucao_1980-1998.pdf.

Acesso em junho de 2020.

BRASIL. Constituição da república federativa do Brasil de 1988. Disponível em http://www.planalto.gov.br/ccivil_03/constituicao/constituicao.htm. Acessada em 05 de maio de 2021.

BRASIL. Lei 9.394/96 - Diretrizes e bases da educação nacional. Disponível em http://www.planalto.gov.br/ccivil_03/leis/l9394.htm. Acesso em 05 de maio de 2021. CARCANHOLO, Marcelo D. A crise do capitalismo dependente brasileiro. In: MACARIO, E. et all (orgs.). 1 ed. Fortaleza; EdUece; Bauru/SP: Canal 6, 2018.

CASIMIRO, Flávio H. C. A nova direita - aparelhos de ação política e ideológica no Brasil contemporâneo. $1^{\text {a }}$ ed. São Paulo: Expressão Popular, 2018.

CHASIN, José. A miséria brasileira (1964-1994): do golpe militar à crise social. São Paulo: Estudos e edições ad hominem, 2000.

CHASIN, José. A determinação ontonegativa da politicidade. In: Ensaios Ad Hominem, política. São Paulo: Estudos e edições ad hominem, 2000.

CORREIA, Ciro T. A apropriação privada da universidade pública - as fundações privadas ditas de apoio. In: RAMPINELLI, W. J. e OURIQUES, N. (orgs.). Crítica à razão acadêmica reflexões sobre a universidade contemporânea. 3 ed. Florianópolis, Insular, 2017.

DEO, Anderson. A consolidação da social democracia no Brasil: forma tardia de dominação burguesa nos marcos do capitalismo de extração prussiano-colonial. 2011. 303 f. Tese (Doutorado em Ciências Sociais) - Universidade Estadual Paulista, Faculdade de Filosofia e Ciências, 2011. Disponível em <http://hdl.handle.net/11449/101001>. Acesso em 19/04/2021.

FILGUEIRAS, Luiz. Padrão de reprodução do capital e capitalismo dependente no brasil atual. Caderno C R H, Salvador, v. 31, n. 84, p. 519-534, set./dez. 2018.

GRANEMANN, Sara. Monetización y financerización de las políticas sociales: expressiones del neodesarrollismo? In: FÉLIZ, M. e PINASSI, M. O. (orgs.). La farsa neodesarrollista y las alternativas populares en América Latina. Ciudad Autónoma de Buenos Aires:

Herramienta, 2017. 
GRANEMANN, Sara. Políticas sociais e financeirização dos direitos do trabalho. Revista Em Pauta , $\mathrm{n}^{\circ}$ 20, Rio de Janeiro: 2007. Disponível em https://www.e-

publicacoes.uerj.br/index.php/revistaempauta/article/view/159. Acesso: em 19 maio 2021.

HARVEY, David. A produção capitalista do espaço. $2^{\text {a }}$ ed. São Paulo: Anablume, 2006.

HARVEY, David. O novo imperialismo. Trad. Adail Sobral e Maria Stela Gonçalves. $2^{\text {a }}$ ed. São Paulo: Edições Loyola, 2005.

HARVEY, David. Neoliberalismo: história e implicações. $5^{a}$ ed. São Paulo: Edições Loyola, 2014.

LUKÁCS, G. Per l'ontologia dell'essere sociale. Roma: Editori Riuniti, 1981.

MARX, Karl; ENGELS, Frederich. A ideologia alemã - crítica da novíssima filosofia alemã em seus representantes Feuerbach, B. Bauer e Stirner, e do socialismo alemão em seus diferentes profetas, 1845-1846. Rio de Janeiro: Civilização Brasileira, 2007.

MARX, Karl; ENGELS, Frederich. Manifesto do partido comunista. 1 ed. São Paulo: Expressão Popular, 2008.

MARX, Karl. O Capital. Crítica da Economia Política. Vol. 1. Tomo. 1. S. Paulo: Nova Cultural, 1983.

MÉSZÁROS, István. Para além do capital - rumo a uma teoria da transição. $1^{\mathrm{a}}$ ed. São Paulo: Boitempo; Campinas/SP: Editora da Unicamp, 2002.

MÉSZÁROS, István. O poder da ideologia. São Paulo: Editora Ensaio, 1996.

MINTO, Lalo W. A educação da miséria: particularidade capitalista e educação superior no Brasil. Tese (Doutorado em educação na Faculdade de Educação da Universidade Estadual de Campinhas/SP). Campinas/SP: 2011. Disponível em:

http://flacso.redelivre.org.br/files/2012/07/160.pdf. Acesso: 10 maio 2020.

OLIVEIRA, Francisco. Os direitos do anti-valor - a economia política da hegemonia imperfeita. Petrópolis/RJ: Vozes, 1998.

POLANYI, Karl. A grande transformação: as origens de nossa época. Trad. Fanny Wrabel. $2^{\mathrm{a}}$ ed. Rio de Janeiro: Campus, 2000.

REIS, Luiz F.; MACÁRIO, Epitácio. Dívida pública e financiamento das universidades federais e da ciência e tecnologia no brasil (2003-2020). Revista práxis educacional, v. 16, 41, p. 20-46 2020. DOI: https://doi.org/10.22481/praxisedu.v16i41.7243. Edição especial.

SAAD FILHO, Alfredo. e MORAIS, Lecio. Brasil: neoliberalismo versus democracia. $1^{\text {a }}$ ed. São Paulo: Boitempo, 2018. 
SAES, Decio. República do capital - capitalismo e processo político no Brasil. $1^{\text {a }}$ ed. São

Paulo: Boitempo, 2001.

SALVADOR, Evilásio.; BEHRING, Elaine.; LIMA, R. de L. de. (orgs.). Crise do capital e fundo público - implicações para o trabalho, os direitos e a política social. São Paulo: Cortez, 2019.

SAMPAIO, Helena. Evolução do ensino superior brasileiro (1808-1990). Documento de trabalho 8/91 do Núcleo de Pesquisa sobre o Ensino Superior (NUPS) da USP. São Paulo: NUPS, 1991.

SILVA JR., Nelson da. O Brasil da barbárie à desumanização neoliberal: do "Pacto edípico, pacto social", de Hélio Pellegrino, ao "E daí?", de Jair Bolsonaro. In: SAFATLE, Wladimir; SILVA JR., Nelson da; DUNKER, Christian. (orgs.). Neoliberalismo como gestão do sofrimento psíquico. Belo Horizonte: Autêntica, 2020.

SVAMPA, Maristela. Del cambio de época al fin de ciclo - gobiernos pregresistas, extractivismo y movimientos sociales en América Latina. Ciudad Autónoma de Buenos Aires: Edhasa, 2017.

TEIXEIRA, Francisco J. S. Pensando com Marx - uma leitura crítico-comentada de O capital. São Paulo: Ensaio, 1995. 